\title{
Derivation of Guidelines for Uranium Residual Radioactive Material in Soil at the Former Baker Brothers, Inc., Site, Toledo, Ohio
}

by M. Nimmagadda, S. Kamboj, and C. Yu

Environmental Assessment Division,

Argonne National Laboratory, 9700 South Cass Avenue, Argonne, Illinois 60439

April 1995

Work sponsored by United States Department of Energy, Office of Environmental Restoration, Washington, D.C. 
This report is printed on recycled paper. 


\section{DISCLAIMER}

This report was prepared as an account of work sponsored by an agency of the United States Government. Neither the United States Government nor any agency thereof, nor any of their employees, make any warranty, express or implied, or assumes any legal liability or responsibility for the accuracy, completeness, or usefulness of any information, apparatus, product, or process disclosed, or represents that its use would not infringe privately owned rights. Reference herein to any specific commercial product, process, or service by trade name, trademark, manufacturer, or otherwise does not necessarily constitute or imply its endorsement, recommendation, or favoring by the United States Government or any agency thereof. The views and opinions of authors expressed herein do not necessarily state or reflect those of the United States Government or any agency thereof. 


\section{DISCLAIMER}

Portions of this document may be illegible in electronic image products. Images are produced from the best available original document. 


\section{CONTENTS}

NOTATION $\ldots \ldots \ldots \ldots \ldots \ldots \ldots \ldots \ldots \ldots \ldots \ldots \ldots \ldots \ldots \ldots \ldots$

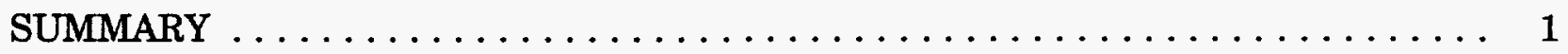

1 INTRODUCTION AND BRIEF HISTORY $\ldots \ldots \ldots \ldots \ldots \ldots \ldots \ldots$

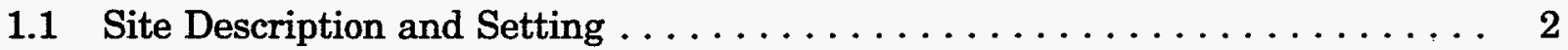

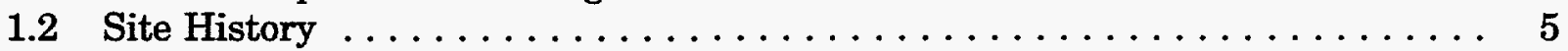

1.3 Derivation of Cleanup Guidelines $\ldots \ldots \ldots \ldots \ldots \ldots$

2 SCENARIO DEFINITIONS $\ldots \ldots \ldots \ldots \ldots \ldots \ldots \ldots \ldots \ldots \ldots \ldots \ldots$

3 DOSE/SOURCE CONCENTRATION RATIOS $\ldots \ldots \ldots \ldots \ldots \ldots \ldots \ldots$

4 RESIDUAL RADIOACTIVE MATERIAL GUIDELINES . . . . . . . . . . . . 15

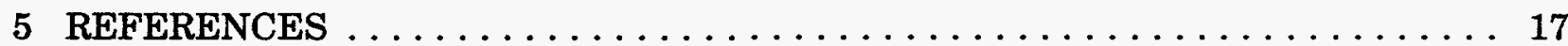

APPENDIX: Scenarios and Parameters Used for the Analysis

of the Former Baker Brothers, Inc., Site . . . . . . . . . . . . . . 19

\section{FIGURES}

1 Map Showing Toledo, Ohio, Location of the Former

Baker Brothers Site $\ldots \ldots \ldots \ldots \ldots \ldots \ldots \ldots \ldots \ldots \ldots \ldots \ldots$

2 Map of the Former Baker Brothers Site Showing Areas of Suspected

Contamination $\ldots \ldots \ldots \ldots \ldots \ldots \ldots \ldots \ldots \ldots \ldots \ldots \ldots \ldots \ldots$

\section{TABLES}

1 Summary of Exposure Pathways for Scenarios A,

$\mathrm{B}$, and $\mathrm{C}$ at the Former Baker Brothers Site $\ldots \ldots \ldots \ldots \ldots \ldots$

2 Maximum Dose/Source Concentration Ratios for Scenario A

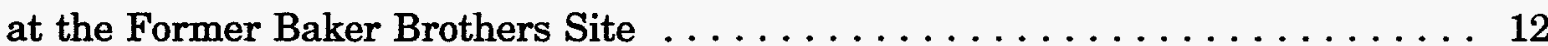

$3 \quad$ Maximum Dose/Source Concentration Ratios for Scenario B

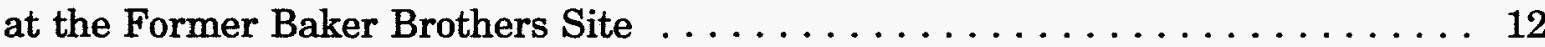

4 Maximum Dose/Source Concentration Ratios for Scenario C at the Former Baker Brothers Site $\ldots \ldots \ldots \ldots \ldots \ldots \ldots$ 


\section{TABLES (Cont.)}

5 Total Dose/Source Concentration Ratios for Uranium at the Former Baker Brothers Site

6 Residual Radioactive Material Guidelines for the Former Baker Brothers Site.

7 Ranges for Hot Spot Multiplication Factors 16

A.1 Parameters Used in the RESRAD Computer Code for the Analysis of the Former Baker Brothers Site 


\section{NOTATION}

The following is a list of the acronyms, initialisms, and abbreviations (including units of measure) used in this document. Some acronyms used only in tables or equations are defined in the respective tables or equations.

\section{ACRONYMS, INITIALISMS, AND ABBREVIATIONS}
AEC
U.S. Atomic Energy Commission
ALARA as low as reasonably achievable
DOE U.S. Department of Energy
FUSRAP Formerly Utilized Sites Remedial Action Program
MED Manhattan Engineer District
ORNL Oak Ridge National Laboratory
RESRAD residual radioactive material guideline computer code
USGS U.S. Geological Survey

\section{UNITS OF MEASURE}

$\begin{array}{ll}\mathbf{c m} & \text { centimeter(s) } \\ \mathbf{c m}^{2} & \text { square centimeter(s) } \\ \mathbf{c m}^{3} & \text { cubic centimeter(s) } \\ \mathrm{d} & \text { day(s) } \\ \mathrm{g} & \text { gram(s) } \\ \mathrm{h} & \text { hour(s) } \\ \mathrm{kg} & \text { kilogram(s) } \\ \mathrm{L} & \text { liter(s) } \\ \mathrm{m} & \text { meter(s) } \\ \mathrm{m}^{2} & \text { square meter(s) } \\ \mathrm{m}^{3} & \text { cubic meter(s) } \\ \mathrm{mg} & \text { milligram(s) } \\ \mathrm{mrem} & \text { millirem(s) } \\ \mathrm{pCi} & \text { picocurie(s) } \\ \mathrm{s} & \text { second(s) } \\ \mathrm{yr} & \text { year(s) }\end{array}$





\title{
DERIVATION OF GUIDELINES FOR URANIUM RESIDUAL RADIOACTIVE MATERIAL IN SOIL AT THE FORMER BAKER BROTHERS, INC., SITE, TOLEDO, OHIO
}

by

\author{
M. Nimmagadda, S. Kamboj, and C. Yu
}

\section{SUMMARY}

Residual radioactive material guidelines for uranium in soil were derived for the former Baker Brothers, Inc., site in Toledo, Ohio. This site has been identified for remedial action under the U.S. Department of Energy's (DOE's) Formerly Utilized Sites Remedial Action Program (FUSRAP). Single-nuclide and total-uranium guidelines were derived on the basis of the requirement that following remedial action, the 50-year committed effective dose equivalent to a hypothetical individual living or working in the immediate vicinity of the site should not exceed a dose constraint of $30 \mathrm{mrem} / \mathrm{yr}$ for the current use and likely future use scenarios or a dose limit of $100 \mathrm{mrem} / \mathrm{yr}$ for less likely future use scenarios (Yu et al. 1993a). The DOE residual radioactive material guideline computer code, RESRAD, was used in this evaluation; RESRAD implements the methodology described in the DOE manual for establishing residual radioactive material guidelines.

Three scenarios were considered; each assumed that for a period of 1,000 years following remedial action, the site would be used without radiological restrictions. The three scenarios varied with regard to the type of site use, time spent at the site by the exposed individual, and sources of food and water consumed. The evaluation indicates that the dose constraint of $30 \mathrm{mrem} / \mathrm{yr}$ would not be exceeded for uranium (including uranium-234, uranium-235, and uranium-238) within 1,000 years, provided that the soil concentration of total combined uranium (uranium-234, uranium-235, and uranium-238) at the former Baker Brothers site did not exceed $710 \mathrm{pCi} / \mathrm{g}$ for Scenario A (industrial worker, current use) or $210 \mathrm{pCi} / \mathrm{g}$ for Scenario B (resident - municipal water supply, a likely future use). The dose limit of $100 \mathrm{mrem} / \mathrm{yr}$ would not be exceeded at the site if the total uranium concentration of the soil did not exceed $500 \mathrm{pCi} / \mathrm{g}$ for Scenario C (subsistence farmer - on-site well water, a plausible but unlikely future use).

The uranium guidelines derived in this analysis apply to the total activity concentration of uranium isotopes (i.e., uranium-238, uranium-234, and uranium-235) present in their natural activity concentration ratio of 1:1:0.046. Consequently, if uranium-238 were measured as the indicator radionuclide, the soil concentration limits for Scenarios A, B, and $\mathrm{C}$ would be 350,100 , and $240 \mathrm{pCi} / \mathrm{g}$, respectively. These guidelines were calculated on the basis of a dose constraint of $30 \mathrm{mrem} / \mathrm{yr}$ for Scenarios A and B and a dose limit of $100 \mathrm{mrem} / \mathrm{yr}$ for Scenario C (Yu et al. 1993a). In setting the actual uranium guidelines for the former Baker Brothers site, DOE will apply the as-low-as-reasonably-achievable (ALARA) policy to the decision-making process, along with other factors such as whether a particular scenario is reasonable and appropriate. 


\section{INTRODUCTION AND BRIEF HISTORY}

The former Baker Brothers, Inc., site is located in Toledo, Ohio. The site has been designated for remedial action by the U.S. Department of Energy (DOE) under its Formerly Utilized Sites Remedial Action Program (FUSRAP). This designation was made after a preliminary inspection by Oak Ridge National Laboratory (ORNL) in June 1989 indicated the presence of uranium contamination both inside and outside of the buildings at the former Baker Brothers site. The former Baker Brothers property was officially included in the FUSRAP program in late 1992 (Foley and Johnson 1993). FUSRAP was established in 1974 by the U.S. Atomic Energy Commission (AEC), a predecessor of DOE. The mandate of the program is to identify, evaluate, and, if necessary, decontaminate sites previously used by the AEC or its predecessor, the Manhattan Engineer District (MED).

Remedial action activities at the former Baker Brothers site will follow the guidelines established in DOE Order 5400.5 (DOE 1990). The DOE residual radioactive material computer code, RESRAD (Yu et al. 1993a), is used to derive residual radionuclide guidelines on a site-specific basis. This report presents the uranium guidelines derived for the former Baker Brothers site on the basis of a dose constraint of $30 \mathrm{mrem} / \mathrm{yr}$ for the current use and likely future use scenarios and a dose limit of $100 \mathrm{mrem} / \mathrm{yr}$ for less likely but plausible future use scenarios (Yu et al. 1993a). The dose constraint of $30 \mathrm{mrem} / \mathrm{yr}$ is not currently required under DOE Order 5400.5, but it is included in the proposed 10 CFR Part 834 rule-making to account for additional dose contributions from other potential sources of radiation exposure.

\subsection{SITE DESCRIPTION AND SETTING}

The Baker Brothers site is located near a downtown area in Toledo (Figure 1), at the intersection of Harleau Place and Post Street. The site encompasses approximately $77,000 \mathrm{~m}^{2}$ and consists of four main buildings. Immediately surrounding the site are commercial businesses to the north and south, residences to the east, and railroad tracks to the west. The property is partially fenced. The exterior ground cover at the site is either asphalt, concrete, or grass, except for a courtyard that is covered with gravel (Figure 2).

The interiors of each of the larger buildings (North and South Buildings) have been subdivided into areas as shown in Figure 2. The South Building is located at 1000 Post Street and is divided into Areas 1, 3, 3A, 4, 5, and 6. This building is $4,200 \mathrm{~m}^{2}$ and is used for offices (Area 1) and electric motor repairs (Areas 3 and 6). Areas 3 and 6 were completely refurbished following a fire that occurred subsequent to MED activities at the former Baker Brothers site (Foley and Floyd 1992). The remainder of the building (Areas 3A, 4, and 5) is completely sealed off and is not currently used.

The North Building, consisting of Areas 7 through 12A, is located at 2555 Harleau Place and is approximately $3,700 \mathrm{~m}^{2}$. Both the building and the small courtyard behind it are used to store electric motors and transformers. 


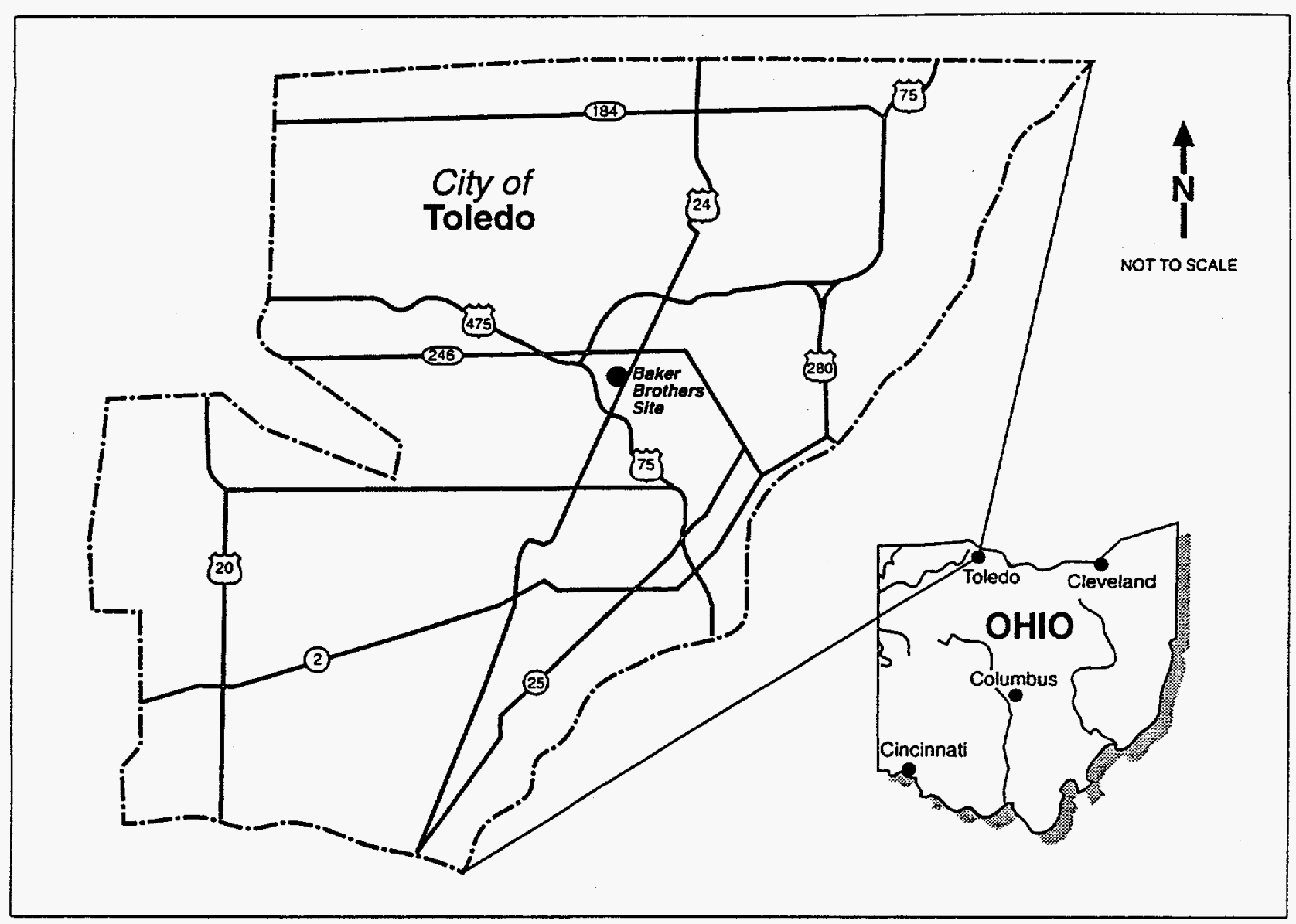

FIGURE 1 Map Showing Toledo, Ohio, Location of the Former Baker Brothers Site (Source: DOE 1995)

The East Building, located at 2551 Harleau Place, is approximately $740 \mathrm{~m}^{2}$ and is a two-story, unoccupied structure formerly used for offices. The building is currently used only for storing office furniture.

The West Building is located on the western edge of the site adjacent to the Conrail property. This two-story building has a high bay area (no second floor) and is $930 \mathrm{~m}^{2}$ in size. This building was previously used as an electric motor shop; however, it is currently unoccupied.

The town of Toledo is located in Lucas County, Ohio. Hydrogeologic information for this area was obtained from Sheets (1995) and the U.S. Geological Survey (USGS) (1991). The annual average precipitation rate for Toledo is $0.82 \mathrm{~m} / \mathrm{yr}$ (USGS 1991). The soil at the site is predominantly sand (USGS 1991). The site currently obtains water from municipal sources, and no wells have been dug on the property. The water table in the area 
Legend

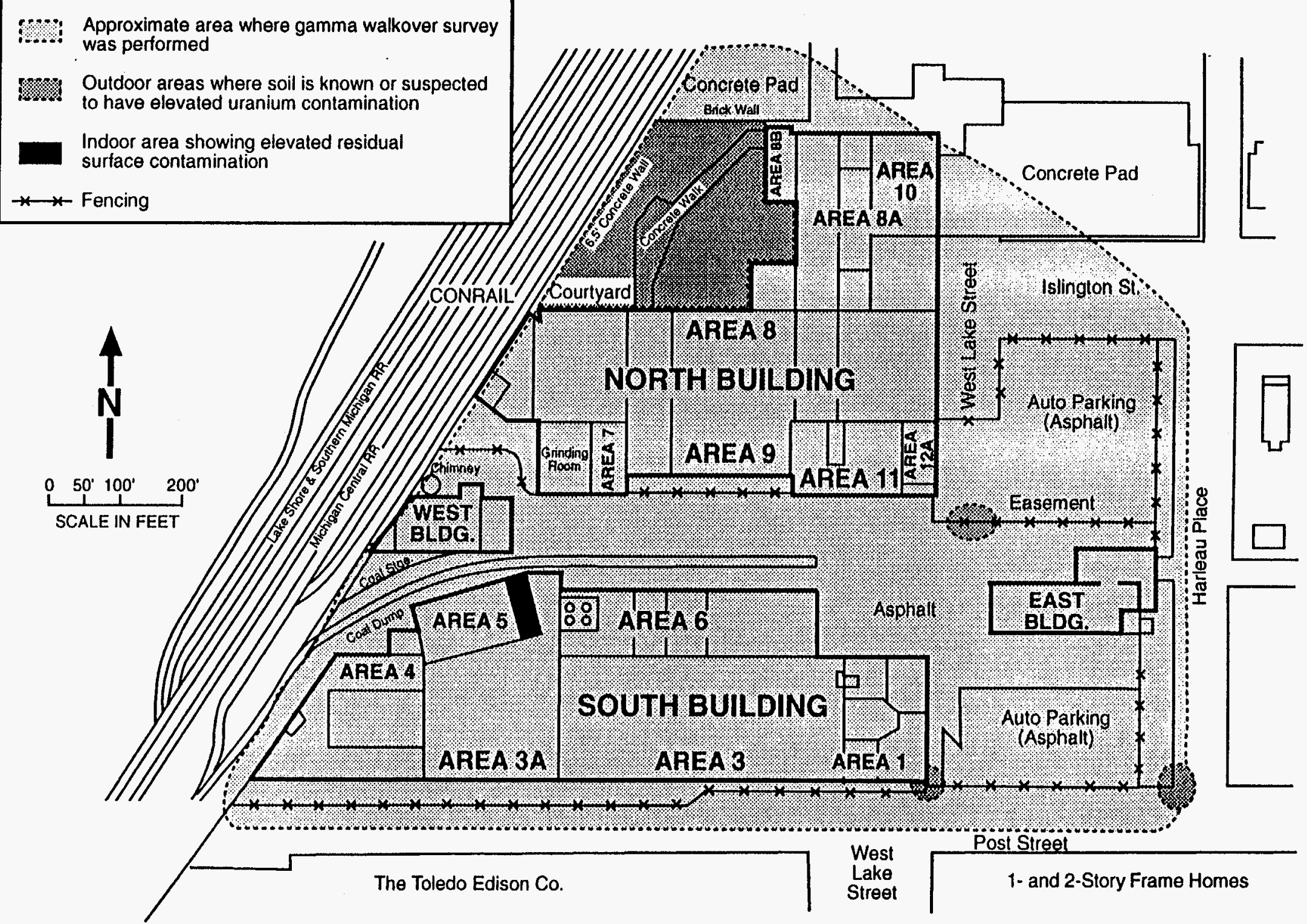

FIGURE 2 Map of the Former Baker Brothers Site Showing Areas of Suspected Contamination (Source: DOE 1995) 
ranges from 6 to $37 \mathrm{~m}$ below the soil surface (Sheets 1995). The distribution coefficient for uranium in surface soil samples collected from the courtyard at the northwestern corner of the property is $128 \mathrm{~cm}^{3} / \mathrm{g}$ (Orlandini 1995).

\subsection{SITE HISTORY}

Between June 1943 and July 1944, the former Baker Brothers site was a subcontractor to the MED. Baker Brothers machined uranium metal rods into slugs for both Clinton Semi-Works in East Tennessee and the Hanford nuclear facility in the state of Washington (Foley and Floyd 1992). The MED contract for this operation was temporary and was discontinued in 1944 when machining operations were transferred to the Hanford facility. The amount of material machined by Baker Brothers was between 90 and 300 tons. The Baker Brothers assets were eventually liquidated, and the machinery and equipment were sold at auction (Foley and Floyd 1992).

According to a Metallurgical Laboratory Health Division report issued on June 21, 1943, heavy fumes were produced by the four lathes used in machining the rods (Foley and Floyd 1992). The pyrophoric uranium chips would spontaneously ignite in the lathe pans and scrap metal containers. An electrostatic precipitator was installed to control the fumes. The cooling system on each of the four lathes was increased to allow greater volumes of lubricant to flow over the turning operation. It is believed that the turning operations were conducted in the grinding room located in the North Building. For security purposes, the uranium scraps were collected and stored for several days to several weeks before shipment off-site (Foley and Floyd 1992).

As a result of the activities performed at the site, equipment, buildings, and land became contaminated with low levels of radioactive material. At MED contract termination, the Baker Brothers site was decontaminated in accordance with the standards and survey methods in use at that time. Since the original assessments, more stringent radiological criteria and guidelines have been implemented for the release of such sites for unrestricted use.

In the absence of substantial information regarding the current condition of the former Baker Brothers site, DOE and Argonne National Laboratory conducted a preliminary radiological survey of the site in April 1981. The preliminary survey results identified a small amount of isolated radioactive contamination in a wooden shelf bin in one building and surface contamination on the floor and wall in another building. No evidence of ceiling or roof contamination caused by the uranium scrap fires was documented in the site records.

Although contamination at the Baker Brothers site was found in only small isolated areas during the preliminary survey, DOE directed that a comprehensive radiological investigation be performed at the site. In June 1989, a team from ORNL performed a radiological survey of the former Baker Brothers site. This survey and sampling effort included all accessible indoor and outdoor portions of the site. In June 1990, subsurface drilling was performed and auger samples were collected. Survey emphasis in building 
interiors was on the floors and overhead beams in all buildings. Survey emphasis exterior to the buildings was on the ground surface and subsurface, as well as the roofs of buildings.

The results of the surveys indicated that one indoor location and four general outdoor areas (Foley and Floyd 1992) had radionuclide concentrations in excess of the DOE guidelines (DOE 1990). On the basis of these surveys, the total outdoor contaminated area is estimated to be approximately $23,000 \mathrm{~m}^{2}$. The areas that contained elevated soil concentrations include the enclosed courtyard (northwest corner of the property), the parking area northwest of the East Building, the southeast corner of the property, and an area on the Post Street property line just east of Area 1 (Figure 2). Indoor measurements were not significantly elevated above DOE guideline values except in some of the shelf bins on the mezzanine of the Area 5 building.

In November 1991, following completion of the ORNL site surveys, private parties excavated and removed contaminated soils and debris from the courtyard at the Baker Brothers property to a location in Ottawa Lake, Michigan (DOE 1994). The courtyard area was then backfilled with gravel.

\subsection{DERIVATION OF CLEANUP GUIDELINES}

Although most DOE cleanup guidelines applicable to remedial actions at FUSRAP sites are generic (DOE 1990), guidelines for uranium are derived on a site-specific basis. The purpose of this analysis was to derive the residual radioactive material guidelines for uranium (i.e., uranium-234, uranium-235, uranium-238, and total uranium) in soil applicable to remedial action at the former Baker Brothers site. The derived guidelines represent the residual concentration of uranium in a homogeneously contaminated area that must not be exceeded if the site is to be released for use without radiological restrictions. The total uranium guideline is derived by assuming that uranium-238, uranium-234, and uranium-235 are present in their natural activity concentration ratio of 1:1:0.046.

Site-specific uranium guidelines for the former Baker Brothers site were derived on the basis of a dose constraint of $30 \mathrm{mrem} / \mathrm{yr}$ for the current use and likely future use scenarios and a dose limit of $100 \mathrm{mrem} / \mathrm{yr}$ for less likely but plausible future use scenarios (Yu et al. 1993a). It was assumed that uranium is the only radionuclide present at an abovebackground concentration. The RESRAD computer code Version 5.43 (Yu et al. 1993a) was used to derive these guidelines. RESRAD implements the methodology described in the DOE manual for establishing residual radioactive material guidelines (Yu et al. 1993a). 


\section{SCENARIO DEFINITIONS}

Three potential exposure scenarios were considered for this assessment of residual radioactivity guidelines for soil. For these scenarios, it was assumed that at some time within 1,000 years, the site will be released for use without radiological restrictions following remedial action. Potential radiation doses resulting from nine exposure pathways were considered: (1) direct exposure to external radiation from decontaminated soil material, (2) internal radiation from inhalation of contaminated dust, (3) internal radiation from inhalation of emanating radon-222, (4) internal radiation from ingestion of plant foods grown in the decontaminated area and irrigated with water drawn from a well located at the downgradient edge of the decontaminated area, (5) internal radiation from ingestion of meat from livestock fed with fodder grown in the decontaminated area and irrigated with water drawn from an on-site well, (6) internal radiation from ingestion of milk obtained from livestock fed with fodder grown in the decontaminated area and irrigated with water drawn from an on-site well, (7) internal radiation from ingestion of fish from a pond downgradient from the decontaminated area, (8) internal radiation from incidental ingestion of on-site soil, and (9) internal radiation from drinking water drawn from an on-site well. All exposure pathways considered for the three scenarios (Scenarios A, B, and C) are summarized in Table 1.

Scenario A (the current use scenario) assumed continued industrial use of the site. Under this scenario, a hypothetical individual was assumed to work 8 hours per day at the site ( 6 hours working indoors and 2 hours outdoors), 5 days per week, 50 weeks per year. It

TABLE 1 Summary of Exposure Pathways for Scenarios A, $B$, and $C$ at the Former Baker Brothers Site

\begin{tabular}{|c|c|c|c|}
\hline Pathway & Scenario $\mathrm{A}^{\mathrm{a}}$ & Scenario $\mathbf{B}^{\mathbf{b}}$ & Scenario $C^{c}$ \\
\hline External gamma exposure & Yes & Yes & Yes \\
\hline Inhalation of dust & Yes & Yes & Yes \\
\hline Inhalation of radon & Yes & Yes & Yes \\
\hline Ingestion of plant foods & No & Yes & Yes \\
\hline Ingestion of meat & No & No & Yes \\
\hline Ingestion of milk & No & No & Yes \\
\hline Ingestion of fish & No & No & Yes \\
\hline Ingestion of soil & Yes & Yes & Yes \\
\hline Ingestion of water & No & No & Yes \\
\hline
\end{tabular}

a Industrial worker: no consumption of water or food obtained on the site.

b Resident: water used for drinking, household purposes, and irrigation is assumed to be from uncontaminated municipal sources.

c Subsistence farmer: water used for drinking, household purposes, livestock watering, and irrigation is assumed to be from an on-site well. 
was also assumed that the worker did not ingest water, plant foods, or fish obtained from the decontaminated area or meat or milk from livestock raised in the decontaminated area. The dose to the worker is assumed to be only from the decontaminated soil.

Scenario B (a likely future use scenario) assumed residential use of the site. It was assumed that at some time in the future, the industrial activities at the site would be discontinued, the existing building would be removed, and the whole site would be transformed into a residential area. A hypothetical resident of the site was assumed to ingest plant foods grown in a garden on the site. All water used by the resident for drinking, household purposes, and irrigation was from municipal sources that are not radioactively contaminated. For this scenario, it was assumed that no livestock are raised on the site for the production of meat and milk and that no pond is present to provide fish or other aquatic food.

Scenario C (a plausible but unlikely future use scenario) is similar to Scenario B, in which a resident was assumed to ingest plant foods grown in the garden. However, under Scenario C, the resident is a subsistence farmer who was also assumed to ingest meat and milk from livestock fed with forage grown on-site and to catch and consume fish and other aquatic organisms from an on-site pond. For this scenario, the groundwater drawn from a well located on-site was the only water source for drinking, household use, livestock watering, and irrigation. Currently no agricultural activity occurs at the site, and production of livestock or construction of a fishing pond in the decontaminated area is considered extremely unlikely. Agricultural use of the property would require removal of the current buildings and paved areas at the site. For the purposes of this analysis, it was assumed that any residual soil contamination would not be removed during the process.

The RESRAD computer code (Yu et al. 1993a) was used to calculate the potential radiation doses for the hypothetical future industrial worker (Scenario $\mathrm{A}$ ), resident (Scenario B), and subsistence farmer (Scenario C) on the basis of the following assumptions:

- During one year, the industrial worker spends 1,500 hours (17\%) indoors at the decontaminated site, 500 hours $(6 \%)$ outdoors at the site, and 6,760 hours $(77 \%)$ away from the site. During one year, the resident and subsistence farmer (Scenarios B and C) spend 4,380 hours (50\%) indoors, 2,190 hours $(25 \%)$ outdoors in the decontaminated area, and 2,190 hours (25\%) away from the site (Yu et al. 1993a).

- The walls, floor, and foundation of the house (Scenarios B and C) or commercial building (Scenario $A$ ) reduce external exposure by $30 \%$. The indoor dust level is $40 \%$ of the outdoor dust level ( $\mathrm{Yu}$ et al. 1993a).

- The airborne dust loading is $0.1 \mathrm{mg} / \mathrm{m}^{3}$.

- The depth of the house or building foundation is $1 \mathrm{~m}$ below ground surface, with an effective radon diffusion coefficient of $3 \times 10^{-7} \mathrm{~m}^{2} / \mathrm{s}$ (Yu et al. 1993a). 
- The size of the decontaminated area is sufficiently large. Of the plant food diet consumed by the resident (Scenario B) and the subsistence farmer (Scenario C), $10 \%$ and $50 \%$, respectively, are grown in a garden in the decontaminated area ( $\mathrm{Yu}$ et al. 1993a). The industrial worker does not consume these plant foods.

- The size of the decontaminated area is large enough to produce $100 \%$ of the forage used to feed livestock for meat and milk consumed by the subsistence farmer in Scenario C (Yu et al. 1993a). The industrial worker in Scenario A and the resident in Scenario B do not consume these animal products.

- For Scenario C, $50 \%$ of the fish and other aquatic food consumed by the subsistence farmer is obtained from an on-site pond ( $Y u$ et al. 1993a).

- The current supply of water for the industrial building is from uncontaminated municipal sources. However, for the plausible but unlikely scenario (Scenario C), the source of water for drinking, household uses, livestock watering, and irrigation is assumed to be an on-site well.

- The soil at the site is predominantly sand (USGS 1991). Because of the lack of site-specific data, typical values for sandy soils tabulated in Yu et al. (1993b) are used for the density, total and effective porosities, soil "b" parameter, and hydraulic conductivity in the contaminated, unsaturated, and saturated zones.

- The uranium distribution coefficient was measured at $128 \mathrm{~cm}^{3} / \mathrm{g}$ for surface soil (Orlandini 1995); this value is used for all uranium isotopes in the contaminated, unsaturated, and saturated zones. The distribution coefficients of the radioactive progeny are those for sandy soils, tabulated in Yu et al. (1993b).

- The annual average precipitation rate for Toledo, Ohio, of $0.82 \mathrm{~m} / \mathrm{yr}$ (USGS 1991) was used. The evapotranspiration coefficient, 0.88 , was calculated as described in Yu et al. (1993b). This value is based on the evapotranspiration rate $(0.61 \mathrm{~m} / \mathrm{yr})$ given in USGS (1991) and assumes a runoff coefficient for a flat residential area.

- No wells have been dug at the site. The water table in the area ranges from 6 to $37 \mathrm{~m}$ below the soil surface (Sheets 1995); a distance of $20 \mathrm{~m}$ to the water table is assumed based on the average water table in area wells. The water table drop rate is assumed to be zero.

- After remedial action, no cover material is placed over the decontaminated area. The erosion rate is assumed to be zero. 
- The depth of contamination, $1.5 \mathrm{~m}$, is based on conservative values from ORNL measurements (Foley and Floyd 1992).

- The area of the contaminated zone was approximated at $23,000 \mathrm{~m}^{2}$, based on the size of the outdoor areas found contaminated during the 1989 and 1990 ORNL surveys. For modeling purposes, these noncontiguous areas are conservatively treated as a single homogeneously contaminated zone of circular shape.

- All other parameters are set to the RESRAD defaults. 


\section{DOSE/SOURCE CONCENTRATION RATIOS}

The RESRAD computer code Version 5.43 (Yu et al. 1993a) was used to calculate the dose/source concentration ratio $D S R_{i p}(t)$ for uranium isotope $i$ and pathway $p$ at time $t$ after remedial action. The time frame considered in this analysis was 1,000 years. Radioactive decay and ingrowth were considered in deriving the dose/source concentration ratios. The various parameters used in the RESRAD code for this analysis of Scenarios A, B, and C are listed in the Appendix. The calculated maximum dose/source concentration ratios for all pathways are presented in Tables 2, 3, and 4 for Scenarios A, B, and C, respectively. For all three scenarios, the maximum dose/source concentration ratios would occur at 1,000 years following remedial action. This is due to the ingrowth of uranium progeny. The dose from natural uranium in soil in Scenarios A and B is contributed by external exposure, inhalation of dust, and inhalation of radon. In Scenario $\mathrm{C}$, the dose from natural uranium is contributed almost equally by the external exposure, dust inhalation, radon inhalation, and plant ingestion pathways.

The summation of $D S R_{i p}(t)$ for all pathways $p$ is the $D S R_{i}(t)$ for the ith isotope,

$$
D S R_{i}(t)=\sum_{p} D S R_{i p}(t)
$$

The total dose/source concentration ratio for total uranium can be calculated as

$$
\operatorname{DSR}(t)=\sum_{i} W_{i} D S R_{i}(t)
$$

where $W_{i}$ is the existing activity concentration fraction in soil at the site for uranium-234, uranium-235, and uranium-238.

For this analysis, $W_{i}$ is assumed to represent the natural activity concentration ratios of $1 / 2.046,1 / 2.046$, and $0.046 / 2.046$ for uranium-238, uranium-234, and uranium-235, respectively. The total dose/source concentration ratios for single radionuclides and total uranium are provided in Table 5. These ratios were used to determine the allowable residual radioactivity for uranium in soil at the former Baker Brothers site.

Uncertainty in the derivation of dose/source concentration ratios arises from the distribution of possible input parameter values, as well as the conceptual model used to represent the site. Depending on the scenario, different parameters affect the results in each case. For Scenarios A and B, the external gamma exposure, dust inhalation, and radon inhalation pathways contribute almost equally to most of the dose. Therefore, uncertainty in parameters affecting these pathways, such as the thickness of the contaminated zone and mass loading of dust in the air, will affect the results more than parameters affecting other pathways. In addition, doses will depend strongly on the choice of occupancy factors selected for these two scenarios. In addition to the external gamma exposure, dust inhalation, and 
TABLE 2 Maximum Dose/Source Concentration Ratios for Scenario A at the Former Baker Brothers Site

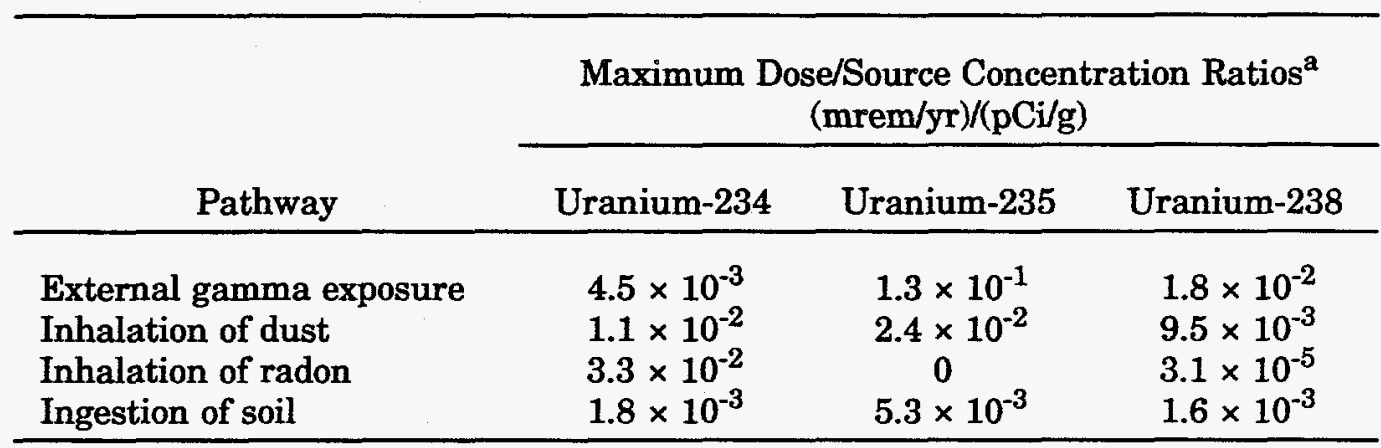

a All values are reported to two significant figures. Maximum dose/source concentration ratios would occur at 1,000 years following remedial action.

TABLE 3 Maximum Dose/Source Concentration Ratios for Scenario B at the Former Baker Brothers Site

\begin{tabular}{lccc}
\hline & \multicolumn{3}{c}{ Maximum Dose/Source Concentration Ratios } \\
& \multicolumn{3}{c}{\begin{tabular}{c} 
a \\
\multicolumn{1}{c}{ Pathrem/yr)/(pCi/g) }
\end{tabular}} \\
\cline { 2 - 4 } \multicolumn{1}{c}{ Pathay } & Uranium-234 & Uranium-235 & Uranium-238 \\
\hline External gamma exposure & $1.5 \times 10^{-2}$ & $4.5 \times 10^{-1}$ & $5.9 \times 10^{-2}$ \\
Inhalation of dust & $3.7 \times 10^{-2}$ & $8.4 \times 10^{-2}$ & $3.3 \times 10^{-2}$ \\
Inhalation of radon & $9.7 \times 10^{-2}$ & 0 & $9.1 \times 10^{-5}$ \\
Ingestion of plant foods & $1.1 \times 10^{-2}$ & $5.3 \times 10^{-2}$ & $8.2 \times 10^{-3}$ \\
Ingestion of soil & $5.7 \times 10^{-3}$ & $1.7 \times 10^{-2}$ & $5.1 \times 10^{-3}$ \\
\hline
\end{tabular}

a All values are reported to two significant figures. Maximum dose/source concentration ratios would occur at 1,000 years following remedial action.

radon inhalation pathways, the plant ingestion pathway also contributes significantly to the dose calculated for Scenario C. Therefore, the guidelines will be sensitive to parameters that affect this pathway, such as root uptake factors and plant ingestion rates.

Because the maximum dose occurs after 1,000 years for all three scenarios, results are affected by uncertainties in the parameters for the leaching of radionuclides from the contaminated zone. It should be noted that the breakthrough time (the time it takes the uranium to reach the water table) does not occur within 1,000 years after remediation and the increase in dose over 1,000 years is caused by the ingrowth of uranium progeny.

The area of the contaminated zone used in this analysis was $23,000 \mathrm{~m}^{2}$, equivalent to the estimated size of the outdoor areas found contaminated during the surveys. If the total area of the site, $77,000 \mathrm{~m}^{2}$, were used in the analysis, the dose/source ratio would increase about $0-2 \%$, depending on the scenario considered. 
TABLE 4 Maximum Dose/Source Concentration Ratios for Scenario C at the Former Baker Brothers Site

\begin{tabular}{|c|c|c|c|}
\hline \multirow[b]{2}{*}{ Pathway } & \multicolumn{3}{|c|}{$\begin{array}{l}\text { Maximum Dose/Source Concentration Ratios } \\
(\mathrm{mrem} / \mathrm{yr}) /(\mathrm{pCi} / \mathrm{g})\end{array}$} \\
\hline & Uranium-234 & Uranium-235 & Uranium-238 \\
\hline External gamma exposure & $1.5 \times 10^{-2}$ & $4.5 \times 10^{-1}$ & $5.9 \times 10^{-2}$ \\
\hline Inhalation of dust & $3.7 \times 10^{-2}$ & $8.4 \times 10^{-2}$ & $3.3 \times 10^{-2}$ \\
\hline Inhalation of radon & $9.7 \times 10^{-2}$ & 0 & $9.1 \times 10^{-5}$ \\
\hline Ingestion of plant foods & $5.7 \times 10^{-2}$ & $2.6 \times 10^{-1}$ & $4.1 \times 10^{-2}$ \\
\hline Ingestion of meat & $3.7 \times 10^{-3}$ & $7.5 \times 10^{-2}$ & $2.7 \times 10^{-3}$ \\
\hline Ingestion of milk & $7.5 \times 10^{-3}$ & $7.0 \times 10^{-3}$ & $6.6 \times 10^{-3}$ \\
\hline Ingestion of fish & 0 & 0 & 0 \\
\hline Ingestion of soil & $5.7 \times 10^{-3}$ & $1.7 \times 10^{-2}$ & $5.1 \times 10^{-3}$ \\
\hline Ingestion of water & 0 & 0 & 0 \\
\hline
\end{tabular}

a All values are reported to two significant figures. Maximum dose/source concentration ratios would occur at 1,000 years following remedial action.

TABLE 5 Total Dose/Source Concentration Ratios for Uranium at the Former Baker Brothers Site

\begin{tabular}{lccc}
\hline & \multicolumn{2}{c}{$\begin{array}{c}\text { Maximum Dose/Source Concentration Ratios } \\
(\mathrm{mrem} / \mathrm{yr}) /(\mathrm{pCi} / \mathrm{g})\end{array}$} \\
\cline { 2 - 4 } & \multicolumn{3}{c}{${ }^{\mathrm{a}}$} \\
Radionuclide & Scenario A $^{\mathrm{b}}$ & Scenario B $^{\mathrm{c}}$ & Scenario C $^{\mathrm{d}}$ \\
\hline & & $1.7 \times 10^{-1}$ & $2.2 \times 10^{-1}$ \\
Uranium-234 & $5.0 \times 10^{-2}$ & $6.0 \times 10^{-1}$ & $8.9 \times 10^{-1}$ \\
Uranium-235 & $1.6 \times 10^{-1}$ & $1.1 \times 10^{-1}$ & $1.5 \times 10^{-1}$ \\
Uranium-238 & $2.9 \times 10^{-2}$ & $1.5 \times 10^{-1}$ & $2.0 \times 10^{-1}$ \\
Total uranium & $4.2 \times 10^{-2}$ & $1.0 \times 1$ \\
\hline
\end{tabular}

a All values are reported to two significant figures.

b Industrial worker: no consumption of water or food obtained on the site (current use scenario).

c Resident: water used for drinking, household purposes, and irrigation is assumed to be from uncontaminated municipal sources (likely future use scenario).

d Subsistence farmer: water used for drinking, household purposes, livestock watering, and irrigation is assumed to be from an on-site well (unlikely but plausible future use scenario). 
The RESRAD default values were used in the calculations when no site-specific data were available. These default values are based on national average or reasonable maximum values. In addition, the contaminated zone thickness of $1.5 \mathrm{~m}$ that was selected to derive the dose/source concentration ratios is based on the assumption that the soil is uniformly contaminated to that depth. In reality, most of the contamination has been detected in the top $60 \mathrm{~cm}$ of soil and is not dispersed uniformly throughout the site. In Scenarios B and C, it is likely that large amounts of potentially contaminated soil and demolition debris would be removed in preparing the site for residential or farming use. Therefore, the calculated dose/source ratios are conservative. 


\section{RESIDUAL RADIOACTIVE MATERIAL GUIDELINES}

The residual radioactive material guideline is the concentration of residual radioactive material that can remain in the soil in a decontaminated area and still allow use of the area without radiological restrictions. Given a dose limit, $D L$, for an individual, the residual radioactive material guideline $G$ for uranium at the former Baker Brothers site can be calculated as

$$
G=D L / D S R
$$

where $D S R$ is the total dose/source concentration ratio listed in Table 5. The dose limit, $D L$, used to derive the residual radioactive material guideline is $30 \mathrm{mrem} / \mathrm{yr}$ for the current use and likely future use scenarios and $100 \mathrm{mrem} / \mathrm{yr}$ for all other plausible future use scenarios (Yu et al. 1993a). The calculated residual radioactive material guidelines for single radionuclides (uranium-234, uranium-235, and uranium-238) and total uranium are presented in Table 6.

For the calculations of the total uranium guidelines (reported to two significant figures), it was assumed that the activity concentration ratio of uranium-238, uranium-234,

TABLE 6 Residual Radioactive Material Guidelines for the Former Baker Brothers Site

\begin{tabular}{lrcc}
\hline & \multicolumn{3}{c}{${\text { Guideline }(\mathrm{pCi} / \mathrm{g})^{\mathrm{a}}}$} \\
\cline { 2 - 4 } Radionuclide & ${\text { Scenario } \mathrm{A}^{\mathrm{b}}}$ & Scenario B $^{\mathrm{c}}$ & Scenario C $^{\mathrm{d}}$ \\
\hline Uranium-234 & 600 & 180 & 450 \\
Uranium-235 & 190 & 50 & 110 \\
Uranium-238 & 1,000 & 280 & 680 \\
Total uranium & 710 & 210 & 500 \\
\hline
\end{tabular}

a All values are reported to two significant figures.

b Industrial worker: no consumption of water or food obtained on the site (current use scenario, dose constraint $=\mathbf{3 0} \mathrm{mrem} / \mathrm{yr}$ ).

c Resident: water used for drinking, household purposes, and irrigation is assumed to be from uncontaminated municipal sources (likely future use scenario, dose constraint $=30 \mathrm{mrem} / \mathrm{yr}$ ).

d Subsistence farmer: water used for drinking, household purposes, livestock watering, and irrigation is assumed to be from an on-site well (unlikely but plausible future use scenario, dose limit = $100 \mathrm{mrem} / \mathrm{yr}$ ). 
and uranium-235 is 1:1:0.046. The derived guidelines for total uranium for Scenarios A, B, and $\mathrm{C}$ are 710,210 , and $500 \mathrm{pCi} / \mathrm{g}$, respectively. If uranium-238 is measured as the indicator radionuclide, the uranium-238 limits for total uranium can be calculated by dividing the total uranium guidelines by 2.046 . The resulting uranium-238 limits for Scenarios A, B, and C are 350,100 , and $240 \mathrm{pCi} / \mathrm{g}$, respectively.

The sum-of-fractions rule applies when the derived radionuclide guidelines for decontamination of a site are implemented. The summation of the radionuclide concentrations $S_{i}$ remaining on-site (averaged over an area of $100 \mathrm{~m}^{2}$ and a depth of $15 \mathrm{~cm}$ ) and divided by their guidelines $G_{i}$ should not be greater than unity, that is,

$$
\sum_{i} S_{i} / G_{i} \leq 1
$$

The derived guidelines listed in Table 6 are for a large homogeneously contaminated area. For a small, isolated area of contamination (a hot spot), the allowable concentration that can remain on-site may be higher than the homogeneous guideline, depending on the size of the contaminated area, and in accordance with the ranges given in Table 7 .

TABLE 7 Ranges for Hot Spot Multiplication Factors

\begin{tabular}{cc}
\hline $\begin{array}{c}\text { Hot Spot } \\
\text { Area Range } \\
\left(\mathrm{m}^{2}\right)\end{array}$ & $\begin{array}{c}\text { Factor } \\
\text { (multiple of } \\
\text { authorized limit) }\end{array}$ \\
\hline & $10^{\mathrm{a}}$ \\
$1-1$ & 6 \\
$3-<3$ & 3 \\
$10-25$ & 2 \\
\hline
\end{tabular}

a Areas less than $1 \mathrm{~m}^{2}$ are averaged over a $1-\mathrm{m}^{2}$ area; average shall not exceed 10 times the authorized limit.

Source: Yu et al. (1993a). 


\section{REFERENCES}

DOE - See U.S. Department of Energy.

Foley, R.D., and L.M. Floyd, 1992, Radiological Survey of the Former Baker Brothers, Inc., Site, 2551-2555 Harleau Place, Toledo, Ohio (BTO001), ORNL/RASA-90/8, prepared by Oak Ridge National Laboratory, Health and Safety Research Division, Oak Ridge, Tenn., for U.S. Department of Energy, Office of Environmental Restoration, March.

Foley, R.D., and C.A. Johnson, 1993, Radiological Survey Results at the 4400 Piehl Road, Ottawa Lake, Michigan (BTO002), ORNL/RASA-93/1, prepared by Oak Ridge National Laboratory, Health and Safety Research Division, Oak Ridge, Tenn., for U.S. Department of Energy, Office of Environmental Restoration, April.

Orlandini, K.A., 1995, personal communication from K.A. Orlandini (Environmental Research Division) to C. Yu (Environmental Assessment Division), Argonne National Laboratory, Argonne, Ill., Feb. 23.

Sheets, R.A., 1995, letter from R.A. Sheets (Ohio District Water Resources Division, U.S. Department of Interior, Columbus, Ohio) to M. Nimmagadda (Environmental Assessment Division, Argonne National Laboratory, Argonne, Ill.), Jan. 26.

U.S. Department of Energy, 1990, "Radiation Protection of the Public and Environment," DOE Order 5400.5, Washington, D.C., Feb. 8.

U.S. Department of Energy, 1994, CX Determination - Removal Action at the Ottawa Lake Residential Property, FUSRAP-029, Oak Ridge Operations Office, Oak Ridge, Tenn., June 13.

U.S. Department of Energy, 1995, unpublished information.

U.S. Geological Survey, 1991, Geohydrology and Quality of Water in Aquifers in Lucas, Sandusky, and Wood Counties, Northwestern Ohio, U.S. Geological Survey Water Resources Investigations Report 91-4024, Columbus, Ohio.

Yu, C., et al., 1993a, Manual for Implementing Residual Radioactive Material Guidelines Using RESRAD, Version 5.0, ANL/EAD/LD-2, prepared by Argonne National Laboratory, Environmental Assessment Division, Argonne, Ill., for U.S. Department of Energy, Office of Environmental Restoration, Washington, D.C., Sept.

Yu, C., et al., 1993b, Data Collection Handbook to Support Modeling the Impacts of Radioactive Material in Soil, ANL/EAIS-8, prepared by Argonne National Laboratory, Environmental Assessment Division, Argonne, Ill., for U.S. Department of Energy, Office of Environmental Restoration, Washington, D.C., April. 


\section{APPENDIX \\ SCENARIOS AND PARAMETERS USED FOR THE ANALYSIS OF THE FORMER BAKER BROTHERS, INC., SITE}

The following exposure scenarios were analyzed for the former Baker Brothers, Inc., site in Toledo, Ohio:

- Scenario A: Industrial Use of the Site. A hypothetical person is assumed to work in the area of the site.

- Scenario B: Residential Use of the Site - Municipal Water Supply. A hypothetical resident is assumed to live in the decontaminated area and to use an uncontaminated municipal water supply for drinking, household purposes, and irrigation. The resident is assumed to ingest plant foods grown on-site; however, no livestock are raised on-site for the production of meat and milk, and no pond is present on-site to provide fish and other aquatic food.

- Scenario C: Subsistence Farming Use of the Site - On-Site Well Water. A hypothetical subsistence farmer is assumed to live in the decontaminated area and to use water from an on-site well for drinking, household purposes, livestock watering, and irrigation. The resident is assumed to ingest plant foods grown in the garden and meat and milk from livestock fed with forage grown on-site. The resident is assumed to catch and consume fish and other aquatic organisms from an on-site pond.

The parametric values used in the RESRAD code for the analysis of the former Baker Brothers site are listed in Table A.1. All parametric values are reported at up to three significant figures. Some values are specific to the former Baker Brothers site; others are generic. 
TABLE A.1 Parameters Used in the RESRAD Computer Code for the Analysis of the Former Baker Brothers Site

\begin{tabular}{|c|c|c|c|c|}
\hline \multirow[b]{2}{*}{ Parameter } & \multirow[b]{2}{*}{ Unit } & \multicolumn{3}{|c|}{ Value } \\
\hline & & Scenario A & Scenario B & Scenario C \\
\hline Area of contaminated zone ${ }^{a}$ & $\mathrm{~m}^{2}$ & 23,000 & 23,000 & 23,000 \\
\hline Thickness of contaminated zone $e^{a}$ & $\overline{\mathbf{m}}$ & 1.5 & 1.5 & 1.5 \\
\hline Length parallel to aquifer flow ${ }^{a}$ & $\mathbf{m}$ & 457 & 457 & 457 \\
\hline Basic radiation dose limit ${ }^{\mathrm{a}, \mathrm{b}}$ & mrem/yr & 30 & 30 & 100 \\
\hline Cover depth ${ }^{\mathrm{a}}$ & $\mathbf{m}$ & 0 & 0 & 0 \\
\hline \multicolumn{5}{|l|}{ Contaminated zone } \\
\hline Density ${ }^{b}$ & $\mathrm{~g} / \mathrm{cm}^{3}$ & 1.5 & 1.5 & 1.5 \\
\hline Erosion rate ${ }^{a}$ & $\mathrm{~m} / \mathrm{yr}$ & 0 & 0 & 0 \\
\hline Total porosity ${ }^{a}$ & $-c$ & 0.39 & 0.39 & 0.39 \\
\hline Effective porosity ${ }^{a}$ & $-^{c}$ & 0.3 & 0.3 & 0.3 \\
\hline Hydraulic conductivity ${ }^{a}$ & $\mathrm{~m} / \mathrm{yr}$ & 5,000 & 5,000 & 5,000 \\
\hline Soil-specific b parameter ${ }^{a}$ & -c & 4.05 & 4.05 & 4.05 \\
\hline Evapotranspiration coefficient $t^{\mathrm{a}}$ & $-^{c}$ & 0.88 & 0.88 & 0.88 \\
\hline Precipitation $^{2}$ & $\mathbf{m} / \mathbf{y r}$ & 0.82 & 0.82 & 0.82 \\
\hline Irrigation $^{b}$ & $\mathrm{~m} / \mathrm{yr}$ & 0.2 & 0.2 & 0.2 \\
\hline Irrigation mode $\mathrm{e}^{\mathrm{b}}$ & $-c$ & Overhead & Overhead & Overhead \\
\hline Runoff coefficient $t^{a}$ & $ـ_{-}^{c}$ & 0.4 & 0.4 & 0.4 \\
\hline Watershed area for nearby pond ${ }^{b}$ & $\mathrm{~m}^{2}$ & Not used & Not used & $1,000,000$ \\
\hline Accuracy for water/soil computation ${ }^{b}$ & $-c$ & Not used & Not used & 0.001 \\
\hline \multicolumn{5}{|l|}{ Saturated zone } \\
\hline Density ${ }^{a}$ & $\mathrm{~g} / \mathrm{cm}^{3}$ & Not used & Not used & 1.5 \\
\hline Total porosity ${ }^{\mathrm{a}}$ & $-c$ & Not used & Not used & 0.39 \\
\hline Effective porosity ${ }^{\mathrm{a}}$ & $-c$ & Not used & Not used & 0.3 \\
\hline Hydraulic conductivity & $\mathrm{m} / \mathrm{yr}$ & Not used & Not used & 5,000 \\
\hline Hydraulic gradient ${ }^{a, b}$ & $-c$ & Not used & Not used & 0.02 \\
\hline Soil-specific b parameter ${ }^{a}$ & $-^{c}$ & Not used & Not used & 4.05 \\
\hline Water table drop rate ${ }^{a, b}$ & $\mathbf{m} / \mathbf{y r}$ & Not used & Not used & 0 \\
\hline Well pump intake depth (below water table) ${ }^{a, b}$ & $\mathbf{m}$ & Not used & Not used & 10 \\
\hline $\begin{array}{l}\text { Model: nondispersion (ND) or mass } \\
\text { balance (MB) }\end{array}$ & $-{ }^{c}$ & Not used & Not used & ND \\
\hline Well pumping rate $\mathbf{a}^{\mathbf{a}, \mathbf{b}}$ & $\mathrm{m}^{3 /} / \mathrm{yr}$ & Not used & Not used & 250 \\
\hline Number of unsaturated zone strata ${ }^{a}$ & $-\mathrm{c}$ & Not used & Not used & 1 \\
\hline \multicolumn{5}{|l|}{ Unsaturated zone } \\
\hline Thickness ${ }^{\mathrm{a}}$ & $\mathbf{m}$ & Not used & Not used & 18.5 \\
\hline Soil density ${ }^{a}$ & $\mathrm{~g} / \mathrm{cm}^{3}$ & Not used & Not used & 1.5 \\
\hline Total porosity ${ }^{a}$ & $-\mathbf{c}$ & Not used & Not used & 0.39 \\
\hline Effective porosity ${ }^{a}$ & $-^{c}$ & Not used & Not used & 0.3 \\
\hline Soil-specific b parameter ${ }^{\mathbf{a}}$ & - $^{c}$ & Not used & Not used & 4.05 \\
\hline Hydraulic conductivity ${ }^{a}$ & $\mathbf{m} / \mathbf{y r}$ & Not used & Not used & 5,000 \\
\hline \multicolumn{5}{|l|}{ Distribution coefficient ${ }^{a}$ (all zones) } \\
\hline Uranium-234 & & 128 & 128 & 128 \\
\hline Uranium-235 & & 128 & 128 & 128 \\
\hline Uranium-238 & & 128 & 128 & 128 \\
\hline Actinium-227 & & 450 & 450 & 450 \\
\hline Protactinium-231 & & 550 & 550 & 550 \\
\hline Lead-210 & & 270 & 270 & 270 \\
\hline Radium-226 & & 500 & 500 & 500 \\
\hline Thorium-230 & & 3,200 & 3,200 & 3,200 \\
\hline Inhalation rate ${ }^{b}$ & $\mathrm{~m}^{3 / y r}$ & 8,400 & 8,400 & 8,400 \\
\hline Mass loading for inhalation ${ }^{a}$ & $\mathrm{~g}^{3} \mathrm{~m}^{3}$ & 0.0001 & 0.0001 & 0.0001 \\
\hline Shielding factor, inhalation ${ }^{\mathrm{b}}$ & $-\mathrm{c}$ & 0.4 & 0.4 & 0.4 \\
\hline Shielding factor, external gamma ${ }^{b}$ & $-c$ & 0.7 & 0.7 & 0.7 \\
\hline Fraction of time indoors $\mathrm{s}^{\mathrm{a}, \mathrm{b}}$ & $-^{c}$ & 0.17 & 0.5 & 0.5 \\
\hline Fraction of time outdoors ${ }^{a, b}$ & $\sim^{c}$ & 0.06 & 0.25 & 0.25 \\
\hline
\end{tabular}


TABLE A.1 (Cont.)

\begin{tabular}{|c|c|c|c|c|}
\hline \multirow[b]{2}{*}{ Parameter } & \multirow[b]{2}{*}{ Unit } & \multicolumn{3}{|c|}{ Value } \\
\hline & & Scenario A & Scenario B & Scenario C \\
\hline Shape factor, external gamma ${ }^{b}$ & $-^{c}$ & 1 & 1 & 1 \\
\hline Dilution length for airborne dust, inhalation ${ }^{b}$ & m & 3 & 3 & 3 \\
\hline \multicolumn{5}{|l|}{ Food consumption } \\
\hline Fruits, vegetables, and grain ${ }^{a, b}$ & $\mathrm{~kg} / \mathrm{yr}$ & Not used & 160 & 160 \\
\hline Leafy vegetables ${ }^{a, b}$ & $\mathrm{~kg} / \mathrm{yr}$ & Not used & 14 & 14 \\
\hline Milk $^{\mathrm{a}, \mathrm{b}}$ & $\mathrm{L} / \mathbf{y r}$ & Not used & Not used & 92 \\
\hline Meat and poultry ${ }^{a, b}$ & $\mathrm{~kg} / \mathrm{yr}$ & Not used & Not used & 63 \\
\hline Fish $^{\mathbf{a}, \mathbf{b}}$ & $\mathrm{kg} / \mathrm{yr}$ & Not used & Not used & 5.4 \\
\hline Other aquatic food ${ }^{\mathrm{a}, \mathrm{b}}$ & $\mathrm{kg} / \mathrm{yr}$ & Not used & Not used & 0.9 \\
\hline Soil ingestion ${ }^{\mathrm{a}, \mathrm{b}}$ & $\mathrm{g} / \mathrm{yr}$ & 36.5 & 36.5 & 36.5 \\
\hline Drinking water intake $e^{a, b}$ & $\mathrm{~L} / \mathrm{yr}$ & Not used & Not used & 510 \\
\hline \multicolumn{5}{|l|}{ Contaminated fraction of food and water } \\
\hline Drinking water ${ }^{a, b}$ & & Not used & 0 & 1 \\
\hline Household water ${ }^{\mathrm{a}, \mathrm{b}}$ & & Not used & 0 & 1 \\
\hline Livestock water ${ }^{a, b}$ & & Not used & Not used & 1 \\
\hline Irrigation water ${ }^{a, b}$ & & Not used & 0 & 1 \\
\hline Aquatic food $\mathrm{a}, \mathrm{b}$ & & Not used & Not used & 0.5 \\
\hline Plant food ${ }^{a, b}$ & & Not used & 0.1 & $0.5^{\mathrm{d}}$ \\
\hline Meat $^{\mathbf{a , b}}$ & & Not used & Not used & $1.0^{\mathrm{d}}$ \\
\hline Milk $^{a, b}$ & & Not used & Not used & $1.0^{d}$ \\
\hline Livestock fodder intake for meat ${ }^{a, b}$ & kg/d & Not used & Not used & 68 \\
\hline Livestock fodder intake for milk ${ }^{\mathrm{a}, \mathrm{b}}$ & $\mathrm{kg} / \mathrm{d}$ & Not used & Not used & 55 \\
\hline Livestock water intake for meat ${ }^{\mathrm{a}, \mathrm{b}}$ & $\mathrm{L} / \mathrm{d}$ & Not used & Not used & 50 \\
\hline Livestock water intake for milk ${ }^{a, b}$ & $\mathrm{~L} / \mathrm{d}$ & Not used & Not used & 160 \\
\hline Livestock soil intake $^{a, b}$ & $\mathrm{~kg} / \mathrm{d}$ & Not used & Not used & 0.5 \\
\hline Mass loading for foliar deposition ${ }^{a, b}$ & $\mathrm{~g} / \mathrm{m}^{3}$ & Not used & 0.0001 & 0.0001 \\
\hline Depth of soil mixing layer ${ }^{b}$ & $\mathbf{m}$ & 0.15 & 0.15 & 0.15 \\
\hline Depth of roots ${ }^{\mathbf{a}, \mathbf{b}}$ & $\bar{m}$ & Not used & 0.9 & 0.9 \\
\hline & \multicolumn{4}{|c|}{ from surface water) } \\
\hline Drinking water ${ }^{\mathrm{a}, \mathrm{b}}$ & & Not used & Not used & 1 \\
\hline Household water ${ }^{\mathrm{a}, \mathrm{b}}$ & & Not used & Not used & $\mathbf{1}$ \\
\hline Livestock water ${ }^{\mathrm{a}, \mathrm{b}}$ & & Not used & Not used & 1 \\
\hline Irrigation $^{\mathbf{a}, \mathbf{b}}$ & & Not used & Not used & $\hat{1}$ \\
\hline Storage times of contaminated foodstuffs & days & & & \\
\hline Fruits, nonleafy vegetables, and grain ${ }^{a, b}$ & & Not used & 14 & 14 \\
\hline Leafy vegetables ${ }^{a, b}$ & & Not used & 1 & 1 \\
\hline Fish $^{a, b}$ & & Not used & Not used & 7 \\
\hline Crustacea and mollusks ${ }^{a, b}$ & & Not used & Not used & 7 \\
\hline Milk $^{\mathrm{a}, \mathrm{b}}$ & & Not used & Not used & 1 \\
\hline Meat and poultry ${ }^{a, b}$ & & Not used & Not used & 20 \\
\hline Well water ${ }^{a, b}$ & & Not used & Not used & 1 \\
\hline Livestock fodder ${ }^{a, b}$ & & Not used & Not used & 45 \\
\hline $\begin{array}{l}\text { Total porosity of the house or building } \\
\text { foundation }{ }^{b}\end{array}$ & $\sim^{c}$ & 0.1 & 0.1 & 0.1 \\
\hline Volumetric water content of the foundation ${ }^{b}$ & $--^{c}$ & 0.03 & 0.03 & 0.03 \\
\hline Diffusion coefficient for radon gas & $\mathrm{m}^{2} / \mathrm{s}$ & & & \\
\hline In foundation material ${ }^{\mathbf{b}}$ & & $3.0 \times 10^{-7}$ & $3.0 \times 10^{-7}$ & $3.0 \times 10^{-7}$ \\
\hline In contaminated zone soil ${ }^{b}$ & & $2.0 \times 10^{-6}$ & $2.0 \times 10^{-6}$ & $2.0 \times 10^{-6}$ \\
\hline Emanating power of radon-222 & $-^{c}$ & 0.25 & 0.25 & 0.25 \\
\hline Radon vertical dimension of mixing ${ }^{b}$ & $\mathbf{m}$ & 2 & 2 & 2 \\
\hline Average annual wind speed ${ }^{b}$ & $\mathbf{m} / \mathbf{s}$ & 2 & 2 & $\mathbf{2}$ \\
\hline Average building air exchange rate ${ }^{b}$ & $1 / \mathrm{h}$ & 0.5 & 0.5 & 0.5 \\
\hline Height of building (room) & $\mathbf{m}$ & 2.5 & 2.5 & 2.5 \\
\hline
\end{tabular}


TABLE A.1 (Cont.)

\begin{tabular}{|c|c|c|c|c|}
\hline \multirow[b]{2}{*}{ Parameter } & \multirow[b]{2}{*}{ Unit } & \multicolumn{3}{|c|}{ Value } \\
\hline & & Scenario A & Scenario B & Scenario C \\
\hline Building indoor area factor ${ }^{b}$ & $-\mathbf{c}$ & 0 & 0 & 0 \\
\hline Bulk density of house or building foundation ${ }^{b}$ & $\mathrm{~g} / \mathrm{cm}^{3}$ & 2.4 & 2.4 & 2.4 \\
\hline Thickness of house or building foundation ${ }^{b}$ & $\mathbf{m}$ & 0.15 & 0.15 & 0.15 \\
\hline Building depth below ground surface ${ }^{b}$ & $\mathbf{m}$ & 1 & 1 & 1 \\
\hline
\end{tabular}

a Values based on site specifications, scenario assumptions, or Yu et al. (1993a,b).

b RESRAD default values.

c Parameter is dimensionless.

d Calculated with the RESRAD computer code. 